\title{
Afghanistan-Russia Cultural and Humanitarian Cooperation
}

\author{
Asef Naderi \\ Ministry of Foreign Affairs of the Islamic Republic of \\ Afghanistan \\ Kabul, Afghanistan \\ E-mail: asef.naderi@gmail.com
}

\author{
Mina Naderi \\ Ministry of Foreign Affairs of the Islamic Republic of \\ Afghanistan \\ Kabul, Afghanistan \\ E-mail: mina.naderi@mail.ru
}

\begin{abstract}
Any state strives to develop its political, economic, security legal and institutional framework that determines its foreign and domestic policy and shows its potential in the world arena. But the need for cultural development becomes an integral part of any state, national, personal education and development. Afghanistan is a country with a rich culture, traditions and customs. The threads of many centuries crossed here. But the legacy of the past cannot constantly work for development. Therefore, in the XX-XXI centuries, Afghanistan needs to develop its cultural ties with other states to enhance its role both in the regional and international political arena.
\end{abstract}

Keywords-culture; historical heritage; Afghanistan-Russia cooperation; rehabilitation; war

\section{INTRODUCTION}

During a long history there was interaction and mixing of different cultures, languages, nations, tribes, religions and even civilizations (Hellenic, Buddhist, Muslim) in Afghanistan. In the 1 st century $\mathrm{AD}$, the country reached an extraordinary flourishing of its economy, trade and culture [1]. In the XX century, Afghanistan actively developed cultural ties with different European and Asian countries.

Due to the political and economic problems caused by a long civil war, Afghanistan cultural interaction with other world had been forgotten for a long time. From the 1970s to the mid-2000s, the situation in the country did not contribute to the development of culture. In the mid-1990s, the Taliban regime came to power and banned any human desire for beauty [2]. Television, cinema, painting and photography as well as music and theater as an activity contradicting the norms of the Islamic religion were banned in Afghanistan on pain of execution. In 2001, the ban was lifted, but the development of culture was also not a priority for the new government. However, after the end of the war with the need to restore the infrastructure the cultural life of society also began to revive. The first beginnings of cultural life appeared at that time: cinemas were opening, television was gaining strength again, music became a part of public life, and it is the Afghan songs that were most popular in the country. In 2001, several private and state-owned TV channels resumed their work, and after a long break they began to show Western films which had been banned during the Taliban rule. Cinematographic art also began to revive, the Afghan Film Organization was re-opened, and produced such movies as Fire Dancer (2002), Osama (2003), Earth and Ashes (2004), Opium War (2008) etc., which awarded international prizes.

\section{REVITALIZING THE CULTURAL LIFE OF AFGHANISTAN AFTER THE WAR: INTERNATIONAL COOPERATION IN THE CULTURAL SPHERE}

After a long period of war and instability almost all cultural objects were destroyed in Afghanistan. In 2001, with the stabilization of the political situation in the country the Afghan Ministry of Information and Culture began to restore the cultural objects. However, the government did not have the money to restore it, international aid was mainly used for defense and economic needs, so the attraction of foreign investment in the cultural sphere became an urgent issue. In early 2002, the then Minister of Foreign Affairs of the Islamic Republic of Afghanistan Abdullah Abdullah appealed to UNESCO to coordinate all international activities to protect the cultural heritage of the country. In May 2002, UNESCO jointly with the Afghan Ministry of Information and Culture organized the International seminar on the Rehabilitation of Afghanistan's Cultural Heritage which brought together not only specialists but also the representatives of the donor countries and various NGOs. The outcomes of the event were the promise to commit more than US \$ 7 million for the cultural heritage of Afghanistan [3]. Thanks to the UNESCO support, a number of projects for the restoration and protection of the Afghan cultural monuments was initiated, and Afghanistan was managed to attract much more than the originally planned US \$ 7 million.

Despite years of destructive war, the Afghan culture continued to be attractive in the world. In 2002, UNESCO jointly with the International Council of Monuments and Sites (ICOMOS) created the expert working group for the Preservation of the Cultural Landscape and Archaeological Remains of the Bamiyan Valley, where the Taliban had destroyed two giant statues of Buddha in 2001. In 2004, works on its restoration began, but for a number of reasons it was stopped in 2011. Now, there were holograms installed in the place where the statues once stood. They were made in 2015 by a couple from China, who spent around US 
$\$ 120,000$ to make it [4]. In 2006, an international team of archaeologists began major excavations near the Afghan capital of Kabul, in Mes Ainak, where the second largest Buddhist complex in Afghanistan is located. But the excavations were complicated by the largest copper deposit in the world there and the mining of this copper ore could significantly affect the development and recovery of the Afghan economy. Afghanistan had to choose between the cultural heritage and the country's economic development. But in 2007, the acceptable compromise was finally found. In November 2007, the state-owned China Metallurgical Group signed a contract with the Afghan government of this copper deposit development and undertook to pay for archaeological research and excavations in return for permission to the copper mining [5].

Thus, after the end of the war, Afghanistan attracted the attention of many historians, archeologists and scientists all around the world. After becoming the president of the Islamic Republic of Afghanistan in 2014, Ashraf Ghani said that the restoration of the cultural institutions of Afghanistan would be one of the main priorities of the Afghan government and people [6]. Currently, the government through the Ministry of Information and Culture supports various newspapers, radio and television stations, as well as initiatives to promote culture, art, tourism and youth in Afghanistan.

\section{CUlTURAL AND HUMANITARIAN COOPERATION BETWEEN RUSSIA AND AFGHANISTAN}

Cultural and humanitarian cooperation is not the main direction of the relations between Afghanistan and Russia, however, Russia along with other countries help restoring the Afghan historical heritage. Immediately after the establishment of the new government of Hamid Karzai in 2001, Russia began to provide humanitarian assistance to Afghanistan. In 2002, Russia provided US \$ 30 million to Afghanistan [7].From 2008 to 2010, Russia also delivered flour and wheat as a food assistance to Afghanistan. During the second half of the 2000 s, Russian humanitarian aid amounted to more than $\$ 40$ million [8].

In recent years, cultural cooperation between two countries has grown rapidly. Interestingly, in addition to public investment individuals also participate in the revival of Afghan culture. In 2010, Russian musician Michael Simonyan began to sponsor the Afghanistan National Institute of Music, which at that time was the only place where Afghans could study music. Mr Simonyan launched the charitable program «Beethoven Not Bullets» [9]; all funds would go to the revival of the Afghanistan's musical culture, which suffered greatly due to a comprehensive ban on music during the reign of the Taliban.

Afghanistan and especially the Soviet-Afghan war left a deep imprint on the lives of Russians. This is manifested in making movies, music and other works of art dedicated to this event. In turn, the Afghan art critic Mamnun Maksudi said that Russia had a great influence on the development of Afghan culture and science [10]. Therefore, there is a certain interest in the development of cultural ties both in Russia and in Afghanistan. In 2011, with the assistance of the Centre for Contemporary Afghan Studies the photo exhibition Modern Afghanistan: Another Look was opened in Moscow. The exhibition was prepared by three photographers from Russia, Brazil and Iran and was devoted not to war, but to the daily lives of Afghans [11]. In 2015, a photo exhibition dedicated to the modern war in Afghanistan Warehouse documents. Iraq. Afghanistan was also held in Moscow. The main theme of the exhibition was drug trafficking as the source of funding for the Taliban. In 2016, the exhibition In Memory: Afghanistan was held in Moscow, it presented the works of photographs taken by war correspondents in 1979-1989.In 2017, Russia hosted an exhibition of paintings made by Afghan artist Zemar Said Kodbuddin which was also devoted to various aspects of life in modern Afghanistan.

There was an increased interest in Russian literature in Afghanistan. In 2012, Lev Tolstoy's novel War and Peace translated into Pashto by Afghan writer Latif Bakhand who graduated from Moscow State University was first released in Afghanistan. At the same time, the Latif Bakhand noted that, unfortunately, because of the ongoing war, the creation of such masterpieces would not possible in Afghanistan in the nearest future [12]. Subsequently, another poem of the Russian author Benedict Yerofeyev Moscow-Petushki was also translated into Pashto by another Afghan writer. In 2017, the book by the Russian ethnographer and writer Pavel Zarifull in New Scythians was translated in Afghanistan. Thanks to the Afghan publicist Hazrat Vakhriz, who made the translation of this book and the Benedict Yerofeyev's poem, the Afghans were also able to get acquainted with the work of Russian poets such as Anna Akhmatova and Nikolay Gumilev.

In 2012, it became known that the construction of the Russian Cultural Center in Kabul began on the site of the House of Soviet Science and Culture, built in 1982 and destroyed during the civil war in the 1990s. It was planned that Russian language classes would be held here. In 2013, the Discovery-2013 Games dedicated to the modern war in Afghanistan were held near the Asbest town, in the Sverdlovsk region, Russia. More than 1.5 thousand people from all over Russia took part in it [13].

Russian-Afghan ties in the field of cinema is developing most rapidly. Afghans love Soviet films, and there is a great interest in movies about the Soviet-Afghan war in Russia. As the Chairman of Afghanistan Cinematographers' Union Javanshir Haydari said: The best Afghan producers and other artists were trained in Moscow [14]. Among them is the well-known producer and director of the Afghan Film Organization Siddiq Barmak, whose films Osama and Opium War won many international film awards, as well as other well-known Afghan figures of art such as singer Khalik Aziz, film director Homayun Morvat and producer Ibrahim Arifi. In 2012, Mr Morovat's film «An Apple from Paradise» was screened in Moscow. In 2013, Homayun Morvat made the film Flying Without Wings in Russia dedicated to the emigration and life of Afghans far from the homeland, as well as the history of the Soviet soldier and the mistakes of the Afghan war. Both Afghan and Russian actors took part in it. In 2016, the Afghan movie Mary Mother directed by 
Sadam Wahidi received the prize of the International Festival of National and Ethnic Cinema Silver Akbuzat in Ufa, Russia. In the same year, the Afghanistan International Women Film Festival was held in Kabul with the participation of Russia at which Russian cultural figures also received awards. In 2016, the daughter of the current President of Afghanistan, Miriam Ghani, announced the project in Moscow What we left unfinished centered around the five little-known unfinished Afghan feature films shot, but never edited, between 1978 and 1992 [15].

An important component of Russian-Afghan humanitarian cooperation is the cooperation in the field of education, because the country needed qualified specialists for economic recovery. The Afghan government paid great attention to restoring universities and schools and to increasing the number of literate people in the country. Particular attention was paid to education among girls, and global community was closely watching this prosses. Afghan President Ashraf Ghani recently announced the expansion of state support for education. Russia, for its part, allocated quotas for free education for Afghan students in higher educational institutions of the country. Until 2010, the number of seats was 80 , and in 2010 its number increased to 100 [7]. Among the universities that annually accepted students from Afghanistan were Moscow State Institute of International Relations (MGIMO University) and the Diplomatic Academy of the Ministry of Foreign Affairs of Russia. A large number of Afghan students were studying at the Peoples' Friendship University of Russia (RUDN University). RUDN University had established the Association of RUDN Alumni and Friends, and Afghan students occupied a special place here. In addition, in 2008, Russia allocated \$ 4 million to the World Bank for the development of higher education in Afghanistan [7], including the restoration of the Kabul Polytechnic University which was built in the 1960s with the support of the Soviet Union.

A special achievement of the Russian-Afghan educational cooperation is the agreement that Russia is now involved in the training of Afghan military personnel. The interest of Afghanistan and Russia in increasing educational projects is also reflected in the fact that most bilateral meetings at various levels discussed issues of education and science, even if the meeting was of a different kind. For example, in 2016, at the third meeting of the Russian-Afghan Intergovernmental Commission on Trade and Economic Cooperation education and science were discussed for the first time at a high level — by the ministers of education of two states.

\section{CONCLUSION}

Today, Afghanistan is slowly recovering from devastating wars. Afghanistan needs financial assistance to restore the country's cultural heritage, since all the money of international assistance coming from Western countries is spent on economic and security recovery. Nevertheless, culture, education and the humanitarian sphere are no less important, although it is paid much less attention. Currently, Russia and Afghanistan are seeking to develop relations in various fields. Today, the main areas of cooperation are political and security. The cultural sphere is the least developed area of bilateral cooperation; however, the contacts are gradually being established. In addition, the Soviet-Afghan war has a great influence on the peoples; in this connection, there is a great interest in this subject both in Russia and in Afghanistan. Thus, we can conclude that Russian-Afghan cooperation in the cultural and humanitarian sphere has great potential and two countries will undoubtedly develop this area of the relations in the future.

\section{REFERENCES}

[1] Korgun, V. G. History of Afghanistan. 20th Century. M.: Russian Academy of Sciences, Institute of Oriental Studies, 2004. 528 p.

[2] Sazhin, V.I. "Parliament in modern Afghanistan". Afghanistan, Iraq Pakistan: time for elections and change. M.: Russian Academy of Sciences, Institute of Oriental Studies, 2006, pp. 57-69.

[3] Manhart, C. "UNESCO's mandate and recent activities for the rehabilitation of Afghanistan's cultural heritage". International Road Racing Championship. 2004. Vol. 86. No 854, pp. 103-115.

[4] Boyko, S., Nedkova, K. Waiting for the Barbarians: World Heritage Sites Under Threat of Destruction // TASS Russian News Agency. URL: http://tass.ru/spec/bamiyan (accessed: 18.03.2018).

[5] Large-scale archaeological excavations continue in Afghanistan // Russia-K.

http://tvkultura.ru/article/show/article_id/142843/(accessed: 18.03.2018)

[6] Social and Cultural Affairs // Embassy of Afghanistan in Washington. URL:https://www.afghanembassy.us/the-embassy/sections/culturalaffairs/ (accessed: 19.03.2018).

[7] Laletin, Y.P. Russian-Afghan relations at the present stage // DocPlayer. URL: http://docplayer.ru/58970768-Rossiysko-afganskieotnosheniya-na-sovremennom-etape.html(accessed: 19.03.2018).

[8] Russia's Foreign Minister Sergey Lavrov's interview with leading news agencies in Afghanistan, March 16, 2009 // Ministry of Foreign Affairs of the Russian Federation. URL: http://www.mid.ru/ru/maps/af/-

/asset publisher/gehUa6O4gSTV/content/id/301998 (accessed 19.03.2018)

[9] Mikhail Simonyan helps to develop the musical culture of Afghanistan // Afghanistan.ru. URL: http://afghanistan.ru/doc/17630.html (accessed: 19.03.2018).

[10] MamnunMaksudi: Afghanistan and Russia should develop cultural ties // Afghanistan.ru. URL: http://afghanistan.ru/doc/99917.html (accessed: 19.03.2018).

[11] Modern Afghanistan: a different look // State Museum of Oriental Art. URL: http://www.orientmuseum.ru/exhibitions/archive/item=266.aspx (accessed: 19.03.2018).

[12] Roman, L.N.Tolstoy's novel War and Peace is translated into Pashto in Afghanistan // Afghanistan.ru. URL: http://afghanistan.ru/doc/53369.html(accessed: 19.03.2018).

[13] An airsoft game dedicated to the fighting in Afghanistan was held near the Asbest // Afghanistan.ru. URL: http://afghanistan.ru/doc/60087.html(accessed: 19.03.2018).

[14] The Chairman of Afghanistan Cinematographers' Union: The best Afghan producers studied in Russia // Afghanistan.ru. URL: http://afghanistan.ru/doc/107458.html (accessed: 19.03.2018).

[15] What We Left Unfinished // Mariam Ghani. URL: http://www.mariamghani.com/work/366 (accessed: 06.10.2018). 